\title{
Accountability Performance Public Service: Community Based Organization Solution for Base Public Service
}

\author{
Rulinawaty ${ }^{1, *}$, Lukman Samboteng ${ }^{2}$, Sofjan Aripin ${ }^{1}$, M. Rachmat Kasmad ${ }^{3}$, \\ Ridho Harta ${ }^{1}$, Ani Susanti ${ }^{4}$ and Syarif Fadillah ${ }^{1}$
}

\author{
${ }^{1}$ Universitas Terbuka, Indonesia \\ ${ }^{2}$ Politeknik STIA LAN Makassar, Indonesia \\ ${ }^{3}$ Universitas Negeri Makassar, Indonesia \\ ${ }^{4}$ Universitas Tadulako, Indonesia. \\ *Corresponding author email: ruly@ecampus.ut.ac.id
}

\begin{abstract}
Community Based Organizations are one of the non-governmental organizations involved in the development of local communities as the main actors. Local communities as local based non-commercial organizations that work on instruments for groups, for people to convey public interests, and for those that related to members to improve and stabilize their lives. Participation is considered an important role as a part of human growth. The main objective of this research is to construct a model for the implementation of public services that involves the participation of local communities so that they are efficient and help local communities obtain fair and non-supportive services. This model tries to solve complex problems in the implementation of Service Public Accountability Performance by involving all stakeholders by using resources so it runs effectively and efficiently. Based on the results of the pattern matching technique and time series showing the implementation of land needs the help of the local community. The local community in this study is Karang Taruna, this community is in an urban village area. As a local community, it will be very easy to organize the community. Karang Taruna also provides facilities for poor communities or beneficiary families for local governments to obtain social justice services.
\end{abstract}

Keywords: Accountability, Community Based Organizations, Karang Taruna, Participatory Public Service

\section{INTRODUCTION}

The current era of globalization demands that governments around the world undertake public sector reform and the implementation of good governance which is legitimized by the existence of public accountability [1]. Accountability is an important concept in implementing public services. Public sector reform in developing countries requires difficult efforts, political reform and legal reform are one of the reform agendas that developing countries must undertake. In addition, governments in developing countries also face the problem of poverty, and the problem of community empowerment towards economic prosperity which is the main agenda in government reform [2].
The governments of developing countries in Asia have negative image, which is reflected in their indifference and low level of trust in the government that became a major issue in governance caused public administration does not function properly [3].

Today's modern government involves local communities in development. The involvement of Community Based Organizations (CBOs) is carried out to intervene in policies in the implementation of public services so run effectively and efficiently [4].

CBOs are considered capable of solving collective problems involving formal institutions. So far, public service providers put aside the wishes of the community, the government is more in dictating what they should do, 
rather than being asked about what they need to make it easier for them to receive public service, and get public services without discrimination. The involvement of CBOs is a way of "empowering" poor communities in the economic, social, and civic fields in developing countries to get out of poverty [5]. Meanwhile accountability is one of the key elements of participation in empowerment, where local people can work, organize, and mobilize resources to solve problems of themselves for common good [6].

This paper argues that the placement of CBOs as the participation of public service providers because they are part of the community. Meanwhile, the accountability of CBOs lies with the people who live in their communities and also with local governments. Therefore, in this research, we will answer the question about how the government empowers local community organizations to participate in public service delivery, and this research will offer a framework for optimizing public service performance and accountability in providing services for poor communities.

\section{THEORETICAL REVIEW}

\subsection{Community-Based Organizations as Public Service}

Citizens often feel the need to come together to gather resources, skills, talents, and time for the common good. This has found in a large number of organized entities such as trade unions, farmer associations, cooperative societies, youth clubs, faith-based groups and women's groups emerging in the community. In recent times, these organizations are often referred to as grassroots or community-based organizations (CBOs) [7].

Although CBOs have a lower status and are involved in a more limited range of activities from non-governmental organizations (NGOs), they assume dominant role increasingly in a number of vital development programs [5].

CBOs are also in a better position to provide local institutional support towards implementing rural development assisted by community empowerment policy projects [8].

Their capacity will also have a positive impact on the development of rural communities. This paper contributes to the debate on how to improve their mode of operation and development.

Public service delivery activities are a core part of CBOs research. CBOs provide services to local residents in two events, namely nonreciprocal and reciprocal. The difference is whether CBOs become part of community activities or service providers that expect that local communities will depend on CBOs to come out of their powerlessness in development participation. CBOs become protectors for poor communities, CBOs carry out cross-sectoral colorizations [9].

\subsection{Community Based Organization for Accountability}

The participatory concept is an entry point for community-based organizations. CBOs are important actors in empowering communities other than the state and non-governmental organizations (NGOs) [10].

Real participation can be seen in CBOs because these institutions are locally based and managed by the community itself. This organization does not have a formal structure so that the participation is more intensive and more authentic. CBOs have a limited number of memberships, so the learning process is easier. Members of this group are very easily influenced to accept new ideas [11].

Community-based organizations (CBOs) define as organizations that provide social services at the local level. It is a non-profit organization primarily based on voluntary efforts. This means that CBOs rely heavily on voluntary contributions for labor and financial support. According to Chechetto-Salles in [12], $\mathrm{CBO}$ is characterized by the following: 1) it is nonprofit; 2) it relies on voluntary contributions; 3 ) it is acts at local level; 4) it is service oriented.

Sarma, Vicary, and Holdrege in [13] defines communitybased organizations as "grassroots organizations managed by members on behalf of members". According to Sarma, Vicary and Holdrege, community-based organizations are identified by 4 characteristics namely local ownership (the organization is owned by the community and serves priorities and aspirations), local accountability (the organization is accountable to society and not to a higher level), local control (members have control over the direction and activities of the organization), and local membership (the organization consists of community members). While Hasenfeld and Gidron in [14] defines a community-based organization as "a group of individuals who experience common problems, to share stories and personal knowledge for each other and to help in any situation for each other. In addition, this group emphasizes face-to-face interaction and informal and interchangeable roles.

Accountability is about the behavior and performance of a person, group, or organization, and how this is assessed [15]. Accountability then is about power, authority, and ownership [16], and determines the relationship between actors through identifying responsible, and owes the task of explanation and improvement [17].

Accountability of CBOs resides in their local communities or beneficiaries, in general there are no laws or regulations that give control rights to their communities for accountability. CBOs' obligation of accountability is to stakeholders such as government and other actors involved in public service, this affects their power ties to their communities.

The perspectives developed by some CBOs working in public service delivery argue that they are part of civil society, and play empowering role in their communities. Representatives of CBOs are generally not based on 
membership selection but based on community representatives, or on their own initiative because they have the same vision and mission to be involved in a community. The role of CBOs more related to the interests of the wider community, among others, alleviating poverty, overcoming poor, achieving social justice and realizing human rights in the provision of public services.

The non-formal structure that is built create a lack of accountability pathways for their communities [18], also create a capacity gap that makes accountability of CBOs more discretionary.

Accountability CBOs function to empower their communities by making members to their local communities and beneficiaries as control tool [19]. But this is a problem in CBOs because the supervision carried out by their local communities or beneficiaries becomes difficult, the accountability they face are multiply, complex and diffuse due to the absence of formal membership in their community that they should responsible.

The relationship created between CBOs and communities or beneficiaries based on voluntary and helping, not on the realm of civil rights relations that must be accounted for. There are three accountabilities that must be fulfilled by $\mathrm{CBO}$ are for their values and mission; for their performance in relation to the mission; and their role as civil society actors. In theory, it is their local communities (the people they serve), actors and supporters, and the state, which should be able to call CBOs to account for these three accountabilities but in practice their local communities have little chance of doing so [20].

\section{RESEARCH METHOD}

\subsection{Research Location}

This research was conducted at local government agencies at the sub-district level, namely the sub-district office in the Makassar City Government area. The scope of the research includes the implementation of the main duties and functions of the sub-district head in carrying out public services, especially related to government civil services for poor communities. Due to the wide area of the research area, the object clustering was carried out by taking a purposive sample of the research location by first determining the criteria for the research object to be studied on the basis of criteria, advanced, moderate and lacking sub-districts in terms of service innovation. The selected research locations were Rappocini District, Bontoala District, and Manggala District.

\subsection{Research Design}

The research used qualitative approach, data sources were obtained directly from several research informants who were considered to be able to provide the required data consisting of heads of sub-district agencies, district government officials, community members who received services, mayors, leaders and related SKPD (Regional Work Unit) agencies.

Research data was collected through data collection instruments in interviews, observation and documentation. To obtain more comprehensive data, focus group discussions were also conducted. Further research data were analysed based on the principles of qualitative data analysis. In data analysis a computer program was also used for qualitative research data analysis with the Nvivo7 data processing program.

\section{RESULTS AND DISCUSSION}

\subsection{CBOs Rule in Government}

This research tries to map the rules of CBOs in government, namely service provision, community development and electoral politics [12]. CBOs provide services and build relationships of trust and collaboration in local environment. But CBOs are more focused on improving and empowering the poor. $\mathrm{CBOs}$ create real increases for the poor in poor neighborhoods [21]. CBOs focus on the activities of the economic and political community, including activities to influence decisions about how public resources are allocated and where the government encourages the private sector to invest.

This research shows the important role of CBOs in providing services and building community potential to trigger the third activity, namely political activity. The law in Indonesia raises the gap that the non-profit law explicitly prohibits CBOs from engaging in most forms of politics, especially as participants, but in fact $\mathrm{CBO}$ are heavily involved in politics, service provision and community development.

By engaging in political strategy, CBOs can influence the political strategies of public resources allocated for social interests. CBOs politically do more political government deals for service availability contracts that can contribute to their neighborhood communities thus potentially. The result of this approach is that $\mathrm{CBO}$ build political machines in urban poor environments, and able to apply the methods of assisting the distribution of public service provision for poor communities.

\subsection{Decentralization and Decentralized Service Delivery}

Decentralization requires the transfer of authority and responsibility for public functions from the central government to subordinates or organizations formed by semi-independent or private governments. Transfers can be through deconcentrating, delegation, devolution or privatization and involve fiscal, administrative, political dimensions and economic power and function. Public services often decentralized include education, health, water, sanitation, public transport, infrastructure, road maintenance, fire, housing and social welfare. 
Table 1 CBOs Rule in Public Services

\begin{tabular}{lccccc}
\hline \multirow{2}{*}{\multicolumn{1}{c}{ CBOs Name }} & \multicolumn{2}{c}{ Service Provision } & \multicolumn{2}{c}{ Community Building } & Electoral \\
\cline { 2 - 5 } & $\begin{array}{c}\text { Non- } \\
\text { reciprocal }\end{array}$ & Reciprocal & $\begin{array}{c}\text { Community } \\
\text { Participant }\end{array}$ & $\begin{array}{c}\text { Organizational } \\
\text { Adherent }\end{array}$ & $\begin{array}{c}\text { Politics } \\
\text { Non-Governmental Organizations (NGOs) }\end{array}$ \\
Karang Taruna Youth Organization & $\mathrm{X}$ & & $\mathrm{X}$ & & $\mathrm{X}$ \\
Community Empowerment Institution (LPM) & & $\mathrm{X}$ & $\mathrm{X}$ & & $\mathrm{X}$ \\
Family Welfare Empowerment (PKK) & & $\mathrm{X}$ & & $\mathrm{X}$ & $\mathrm{X}$ \\
\hline
\end{tabular}

Table 2 Types and Dimensions of Decentralization

\begin{tabular}{lllll}
\multicolumn{1}{c}{ Type } & Deconcentrating & Delegation & Devolution & Privatization \\
\hline Administrative & & & \\
Physical & & & \\
Politic & & & \\
Economy & & & \\
\hline
\end{tabular}

This is a service that must have overflow to community organizations. In practice, the delegation of authority to public services is complex. Table 2 shows the deconcentrating of administrative responsibility within one government agency to devolving power over all basic services to semi-autonomy.

As shown in Table 1, there are four main dimensions of decentralization that produce at least four types of decentralized systems, namely as follows.

1. Administrative decentralization involving the transfer of the central government bureaucracy to the local level: (a) Deconcentrating, in which the authorities at the sub-national level plan and provide services while remaining fully accountable to the central government. Here there is the involvement of residents in collaboration with local officials. Deconcentrating can meet citizen expectations and ensure equity in resources, stability and consistency of resource allocation and skilled labor from local populations; (b) Delegation whereby the central government transfers responsibility for providing services to $\mathrm{CBO}$ or the private sector which is fully accountable to the ministry that gives authority. Public service deletion authorities can be granted to CBOs through charging fees for services rendered.

2. Political decentralization, also often called democratic decentralization, requires the transfer of power and administrative, fiscal and political functions in providing public services to local governments. This model is one of the broadest models for local government to provide the power to decide and to apply in jurisdiction. This model expects the government to be accountable to the public, CBOs are accountable horizontally to elected officials, while elected officials are accountable to central government. The politics of decentralization is seen as the most conducive technique for citizens to participate effectively in influencing policies.
3. Physical Decentralization. This decentralization used physical cooperation mechanisms in various sectors of public revenue at all levels of government, such as clear expenditure responsibility assignment mechanisms, clear revenue responsibilities, intergovernmental physical transfer mechanisms from central to local governments and authorization for loans and revenue mobilization through loan guarantees from the central government to the World Bank. Physical decentralization is rare but accompanies decentralized politics and administration. Decentralization is carried out to facilitate and increase citizen participation in identifying citizens in sustainable development priorities, in noting that the main role of the government and CBOs is to ensure that resources are applied economically, efficiently and effectively for community to develop in public service.

4. Economic Decentralization. Decentralization includes privatization of state companies (BUMN) and deregulation of the market. This includes three aspects, namely enabling the private sector to perform functions that have been monopolized by the government; contracts for the provision or management of public services or providing facilities to CBOS, funding public sector programs through the capital market. Deregulation requires regulatory changes in policy to allow a greater role for non-state actors such as CBOs in the provision of public services.

\subsection{A new framework for $\mathrm{CBO}$ s accountabilities as public service}

CBOs serve as an effective channel to route various service developments for poor communities [22]. Several donor agencies and external agencies are involved in development policy projects and driven to empower the poor [23]. CBOs were formed to lead the implementation 
of public policies in the realm of public services. However, research shows that CBOs are very appropriate to fit into local culture and are suitable for devoting skills, services and resources to the development of urban and rural poor [24].

The ability of CBOs to advance the development efforts of the urban poor depends on their changing to be effective [21]. Become an agent of change through a number of capacity building schemes, CBOs are the most appropriate organizations in implementing participatory, development initiatives that come from local communities and the need for local governments and private parties. CBOs are the key to community-based development [25]. CBOs are engaged in socio-economic development activities, transformation, collective social action, increased resource allocation and other development activities. Moreover, CBos are important in urban poor communities and rural communities with higher development requirements.

\subsection{Strategies to Strengthen $\mathrm{CBOs}$}

CBOs need various forms of support so that they can make productive contributions to the development of the rural poor [26]. Support in the form of financial grants, donations of IT equipment and provision of other forms of assistance, sometimes provided by several NGOs can increase their operation, but often temporarily. However, strengthening capacity can impact long-term performance and efficiency and therefore should be greater benefit to them and local communities.

Beyond capacity building, three things need to be measured, namely (1) Leadership building (2) Linkages and networking (3) Registering with official agencies. This can reduce their informal character, but remains significantly informal which has characterized CBOs such as the ease of joining a community that is interested in becoming a member without the need for formal applications, interviews, selection as in formal organizations.

CBOs are indeed locally based, carry out activities in their environment, use local languages in their interactions and use local media of communication. Such information will enable CBOs to continue to be an attractive option for those seeking social interaction and avenues for collective action, cooperative development and mutual cooperation. at the same time, increasing their capacity to respond to the growing challenges of developing the urban and rural poor.

\section{CONCLUSION}

Today's modern government is how to involve local communities in development. The involvement of Community Based Organizations (CBOs) is carried out to intervene in policies in the implementation of public services so that they run effectively and efficiently. CBOs are considered capable of solving collective problems involving formal institutions. The involvement of CBOs is a way to "empower" marginalized communities in the economic, social, and citizenship fields in developing countries to move out of poverty.

The conclusion of this research, CBOs as a service provision and build community potential to trigger the third activity, namely political activity. The law in Indonesia raises the gap that the non-profit law explicitly prohibits CBOs from engaging in most forms of politics, especially as participants, but in fact CBOs are heavily involved in politics, apart from being involved in service provision and community development.

CBOs must be designed not to get involved in practical politics. Because these CBOs are locally based, carry out activities in their environment, use local languages in their interactions and use local communication media. Such informality will enable CBOs to continue to be an attractive option for those seeking social interaction and avenues for collective action, cooperative development and mutual support while, at the same time, increasing their capacity to respond to the growing challenges of developing the urban poor. and countryside.

\section{REFERENCES}

[1] A. H. Church, L. M. Dawson, Agile feedback drives accountability and sustained behavior change. Strategic HR Review, 17 (6) (2018), 295-302.

[2] F. Fischer, Participatory Governance: From Theory to Practice, in Readings in Planning Theory, Fourth Edition. The Oxford Handbook of Governance, 2016.

[3] Rulinawaty, S. Arifin, L. Samboteng, Leading Agile Organization Can Indonesian Bureaucracy Become Agile?. Journal of Talent Development and Excellence, 12 (3s) (2020), 330-338.

[4] R. Kasmad, L. Samboteng, A. Mahsyar, The Unwise Policy of Community Based-Organisation: Can It Empower Them? Implementation Network of Food Diversification in Indonesia. OPCION, 35 (22) (2019), 2899-2921.

[5] B. Dill, Community-Based Organizations (CBOs) and Norms of Participation in Tanzania: Working against the Grain. African Studies Review, 53 (2) (2010), 23-48.

[6] J. Arcand, M. Fafchamps, Matching in communitybased organizations. Journal of Development Economics, 98 (2) (2012), 203-219.

[7] E. O. Afoakwa, Cocoa Production and Processing Technology. Boca Raton: CRC Press, 2014. 
[8] M. C. Morales, L. M. Harris, Using subjectivity and emotion to reconsider participatory natural resource management, World Development, 64 (2014), 703-712.

[9] L. Samboteng, R. Kasmad, Network-Based Information System Organization in Defining A Strategy. Borneo Administrator, 10 (2) (2014), 234252.

[10] S. Gailmard, J. W. Patty, Participation, process and policy: The informational value of politicised judicial review. Journal of Public Policy, 37 (3) (2017), 233260.

[11] O. Marnet, Explaining governance failure: accountability spaces in-between and bias. International Journal of Critical Accounting, 6 (4) (2015), 27 pages.

[12] Y. Geyer, Project management: handbook series for community-based organisations. Institute for Democracy in South Africa (IDASA), 2005.

[13] G. D. Mgawanyemba, Community-based Organizations in Socio-economic Development: The Experience of Kasungu District in Malawi. Dissertation of University of South Africa, Pretoria, 2008.

[14] B. C. Feld, Criminalizing the American Juvenile Court. Crime and Justice, 17 (1993), 197-280.

[15] L. I. Lopez, B. C. Garcia, Starting early: relational capital networks for street children in emerging knowledge-based public service models. International Journal of Knowledge-Based Development, 7 (1) (2016), 43-62.

[16] Alwi, R. Kasmad, Dilemma of Values in Public Policy Accountability: Implementation of the Street Vendors Empowerment Policy Networking in Makassar City. The Sixth Asian Conference on Business \& Public Policy, (2015), 1-14.

[17] J. Speer, Participatory Governance Reform: A Good Strategy for Increasing Government Responsiveness and Improving Public Services?. World Development, 40 (12) (2012), 2379-2398.

[18] A. Alwi, A. Aslinda, G. Susanti, Cross-Sector Collaboration and Public Policy Accountability: Implementation Network of Food Security Policy in Bone Regency. Iapa Proceedings Conference, (2019), 88-102.

[19] A. Hall, G. R. Ferris, Accountability and ExtraRole Behavior. Employee Responsibilities and Rights Journal, 23 (2) (2011), 131-144.
[20] R. Kasmad, Democratic Model of Public Policy Accountability. Case Study on Implementation of Street Vendors Empowerment Policy in Makassar City. Studi Pemerintahan, 6 (2) (2015), 1-17.

[21] A. A. Abegunde, Accomplishment Index Analysis of the Sociophysical Activities of Community-Based Organizations in a Postconflict Area of Africa. SAGE Open, 7 (2) (2017), 1-25.

[22] M. Nkimbeng, L. Roberts, R. J. Thorpe Jr., L. N. Gitlin, A. Delaney, E. K. Tanner, S. L. Szanton, Recruiting Older Adults with Functional Difficulties into a Community-Based Research Study: Approaches and Costs. J Appl Gerontol., 39 (6) (2020), 644-650.

[23] P. Sabatier, D. Mazmanian, The Implementation of Public Policy: A Framework of Analysis. Policy Studies Journal, 8 (1980), 538-560.

[24] D. Adams, M. Hess, Community in public policy: Fad or foundation?. Australian Journal of Public Administration, 60 (2) (2001), 13-23.

[25] C. K. C. Chan, Community-based organizations for migrant workers' rights: The emergence of labour NGOs in China. Community Development Journal, 48 (1) (2013), 6-22.

[26] M. G. Wilson, J. N. Lavis, A. Guta, Communitybased organizations in the health sector: A scoping review. Health Research Policy and Systems, 10 (26) (2012), 9 pages. 